\title{
Basal Cell of the Squamous Epithelium
}

National Cancer Institute

\section{Source}

National Cancer Institute. Basal Cell of the Squamous Epithelium. NCI Thesaurus. Code C61604.

A basal cell located in the squamous epithelium. 